\title{
Effect of Nutrients and Cellobiose Octaacetate on Cellulolytic Enzyme Productions by Streptomyces albolongus
}

\author{
Sanjit Kumar Das, M Zobaidul Alam, M Abul Manchur and M Nural Anwar* \\ Department of Microbiology, University of Chittagong, Chittagong 4331, Bangladesh
}

[Received 28 September 2006; Accepted 21 April 2007]

\begin{abstract}
The cellulolytic mesophilic isolate Streptomyces albolongus $\left(\mathrm{A}_{5}\right)$ was used to determine the effect of nitrogen and carbon sources on the production of cellulolytic enzymes using cellobiose octaacetate (COA) as an inducer. The isolate was able to degrade various cellulosic carbon sources. However, the rate of degradation, production of extracellular protein, reducing sugar, saccharification and production of enzyme were enhanced when $0.6 \%$ COA was used as an inducer in addition to the main substrate. Among the nitrogen sources tested, beef extract showed maximum production of the enzyme $(136.7 \mathrm{U} / \mathrm{ml} \mathrm{CMCase)}$ in Winstead's medium. The enzyme production was further enhanced in the medium supplemented with $0.6 \% \mathrm{COA}$, which corresponded to $154.69 \mathrm{U} / \mathrm{ml}$ CMCase activity. Among the carbon sources, carboxymethylcellulose (CMC) was found to be the best carbon source and again supplementation of the medium with $0.6 \%$ COA enhances CMCase production. Other than CMCase activity, the organism also produced appreciable levels of filter paper cellulase (FPase), avicelase and â-glucosidase activities.
\end{abstract}

Keywords: Streptomyces albolongus, Carboxymethylcellulose (CMC), Cellobiose octaacetate (COA), Induction

It has been known that the synthesis of cellulolytic enzymes in microorganisms is regulated by induction and repression system ${ }^{1}$. Cellulase of most microbes is strongly induced by cellulose or the compounds related to its hydrolytic products ${ }^{2}$ and repressed by readily metabolizable carbon sources such as glucose $\mathrm{e}^{3}$. However, the exact role of a compound to act as an inducer or a repressor varies from organism to organism. Cellobiose is a strong inducer in Neurospora crassa ${ }^{4}$ and Sporotrichum pulverulentum ${ }^{1}$ but it is a relatively poor inducer in Trichoderma resse $i^{5}$ when compared with saphorose. In cellulose-producing microbes, cellulose is a common inducer of cellulase formation ${ }^{6-7}$. Since cellulose is insoluble and impermeable to organism's soluble oligosaccharides such as cellobiose, lactose or saphorose is considered to act as a direct inducer of cellulase ${ }^{8-11}$. Of these oligosaccharides, cellobiose is a common product formed from cellulose by exo-cellobiohydrolase and is considered to be a natural inducer ${ }^{12}$. Cellobiose octaacetate was found to be solubilized by acetyl esterase secreted into the culture broth ${ }^{13}$ and the hydrolysate consisting of a series of acetylcellobioses including mono-, di-, tri-O-acetylcellobioses could stimulate cellulase induction ${ }^{14}$. In this study, cellulose production by an actinomycete isolate, Streptomyces albolongus $\mathrm{A}_{5}$, was investigated using cellobiose octaacetate (COA) as an inducer for cellulose biosynthesis.

Streptomyces albolongus $\mathrm{A}_{5}$ was isolated from saw dust on selective cellulolytic medium and identified using standard procedure ${ }^{15}$. Unless otherwise stated, cellulase production was carried out in shake-flask cultures in Winstead's medium with an initial $\mathrm{pH} 6.5$ containing $1.2 \%$ carboxymethylcellulose (CMC) with or without supplementation of $0.6 \%$ cellobiose octaacetate (COA) at $35^{\circ} \mathrm{C}$ for 5 days. After incubation, the culture filtrates were centrifuged to remove cells and other solids and the clear culture supernatants were used for enzyme assay and other analyses. Reducing sugar in the culture filtrates and the enzyme assay mixtures was estimated by using Nelson's modification of Somogyi method ${ }^{16}$ using glucose as standard. Soluble protein in culture filtrates was estimated following the method described by Lowry et al. ${ }^{17}$. The absorbance was read at $650 \mathrm{~nm}$. Culture filtrates obtained by growing the organism on CMC medium was used for estimation of the degree of saccharification (\%) using the following equation: Degree of saccharification (\%) = Reducing sugar (mg/ $\mathrm{ml}$ ) / Substrate concentration (mg/ml) x 100.

Carbooxymethylcellulase (CMCase) activity was determined by mixing $2 \mathrm{ml}$ of culture supernatant to $2 \mathrm{ml}$ substrate (1\%CMC in phosphate buffer, $\mathrm{pH}$ 6.5), $1 \mathrm{ml}$ of phosphate buffer and incubating the reaction mixture at $35^{\circ} \mathrm{C}$ for $2 \mathrm{~h}$. Filter paper cellulase (FPase) was measured by incubating $2 \mathrm{ml}$ of culture supernatant in $1 \mathrm{ml}$ of phosphate buffer (pH 6.5) containing $50 \mathrm{mg}$ Whatman No. 1 filter paper strip $(1 \times 6 \mathrm{~cm})$ in a test tube. The reaction mixture was incubated at $35^{\circ} \mathrm{C}$ for $2 \mathrm{~h}$. For determination of avicelase and $\beta$-glucosidase activities, $1 \%$ avicel and $1 \%$ salicin in phosphate buffer (pH 6.5) respectively were used as substrates. The amount

*Corresponding author:

Dr. M Nural Anwar, Professor, Department of Microbiology, University of Chittagong, Chittagong 4331, Bangladesh

Tel (Office): (031) 682031-39/4464; Tel (Home): (031) 681688; Fax: +880 (031) 726310; E-mail: anwarmn54@yahoo.com 
of reducing sugars released, as glucose equivalents, in the enzyme reactions for CMCase, FPase, avicelase, or $\beta$-glucosidase assay was measured by Nelson-Somogyi method ${ }^{16}$. Enzyme activity was expressed in terms of the amount of glucose released in $\mathrm{mg} / \mathrm{ml}$ by the action of the crude enzyme on the respective substrates per hour according to Mahadevan and Sridhar ${ }^{18}$.

The effect of medium $\mathrm{pH}$ and incubation temperature on liquefaction of CMC in Winstead's medium by Streptomyces albolongus $\mathrm{A}_{5}$ isolate was studied. Maximum liquefaction was observed in the culture media with initial pH between 6.5 and 7.5. High liquefaction at $\mathrm{pH} 6.5$ to 7.5 was also reported by several investigators $^{19-22}$. The liquefaction was more pronounced at $\mathrm{pH}$ 5.5 when the CMC medium was supplemented with $0.6 \%$ cellobiose-octaacetate (COA). This indicates that COA acts as an inducer of cellulase in this organism. The isolate showed highest liquefaction at temperature between $35^{\circ}$ and $40^{\circ} \mathrm{C}$. Similar result was reported by other investigators using mesophilic organisms $^{19-20,22}$.
Table 1 shows the effect of various nitrogen sources in Winstead's medium containing 1.2\% CMC as substrate and COA as an inducer. Beef extract was found to be the best nitrogen source for production of CMCase and the enzyme activity was greatly enhanced in presence of the inducer COA (136.7 unit/ml vs. 154.7 unit/ml). Reducing sugar and soluble protein released as well as the degree of saccharification were highest in the medium containing beef extract, which was followed next by asparagines. In every case higher values were observed in the medium supplemented with COA.

The effect of various cellulosic substrates on productions of extracellular cellulase, soluble protein, reducing sugar, and degree of saccharification is summarized in Table 2. Among the substrates used CMC supported good growth and maximum CMCase (120.2 unit/ml) production by the organisms. CMCase activity was about 4-fold lower in the medium containing avicel or filter paper as substrate. The levels of reducing sugar, soluble protein and degree of saccharification were also highest on the CMC-containing medium. Other than CMCase activity, the organism produced appreciable levels of other cellulase activities like FPase (46.9 unit/ml), avicelase (49.2 unit/ml) and $\beta$-glucosidase (36.8 unit/ml) (Table 3).

Table 1. Effect of various nitrogen sources in Winstead's medium on substrate liquefaction, release of reducing sugar, degree of saccharification, level of extracellular protein and CMCase activity by Streptomyces albolongus $A_{5}$

\begin{tabular}{lcccccc}
\hline $\begin{array}{l}\text { Nitrogen source } \\
(0.2 \%)\end{array}$ & Liquefaction & $\begin{array}{c}\text { Final } \\
\mathrm{pH}\end{array}$ & $\begin{array}{c}\text { Reducing } \\
\text { sugar } \\
(\mathrm{mg} / \mathrm{ml})\end{array}$ & $\begin{array}{c}\text { Saccharification } \\
(\%)\end{array}$ & $\begin{array}{c}\text { Soluble } \\
\text { protein } \\
(\mathrm{mg} / \mathrm{ml})\end{array}$ & $\begin{array}{c}\text { CMCase } \\
\text { activity } \\
(\text { Unit/ml })^{\mathrm{a}}\end{array}$ \\
\hline $\begin{array}{l}\text { In presence of 1.2\% CMC } \\
\text { Asparagine }\end{array}$ & +++ & 8.4 & 296.9 & 2.47 & 182.7 & 118.2 \\
Beef extract & ++++ & 8.1 & 309.4 & 2.58 & 196.4 & 136.7 \\
$\quad\left(\mathrm{NH}_{4}\right)_{2} \mathrm{SO}_{4}$ & ++ & 7.2 & 160.2 & 1.33 & 117.7 & 68.7 \\
Urea & ++ & 8.0 & 87.5 & 0.73 & 96.4 & 38.3 \\
In presence of 1.2\% CMC plus 0.6\% COA & & & & & & \\
Asparagine & ++++ & 6.8 & 311.7 & 2.60 & 199.5 & 138.7 \\
Beef extract & ++++ & 7.1 & 325.8 & 2.72 & 225.4 & 154.7 \\
(NH $)_{2} \mathrm{SO}_{4}$ & ++ & 6.2 & 87.5 & 0.73 & 96.4 & 75.3 \\
Urea & ++ & 7.2 & 84.4 & 0.70 & 100.0 & 60.2 \\
\hline
\end{tabular}

The organism was grown in shake-flask culture in Winstead's medium with an initial $\mathrm{pH} 6.5$ containing $1.2 \%$ carboxymethylcellulose (CMC) with or without supplementation of $0.6 \%$ cellobiose octaacetate (COA) at $35^{\circ} \mathrm{C}$ for 5 days. ${ }^{a}$ One unit of the enzyme activity was defined as the amount of enzyme required to release glucose equivalents (in $\mathrm{mg} / \mathrm{ml}$ ) in $1 \mathrm{~h}$ under the defined conditions. CMCase $=$ Carboxymethylcellulase; $(-)=$ No liquefaction; $(+)=$ Slight liquefaction; $(++)=$ Low liquefaction; $(+++)=$ Moderate liquefaction; $(++++)=$ Heavy liquefaction.

Table 2. Effect of various nitrogen sources in Winstead's medium on release of reducing sugar, degree of saccharification, level of extracellular protein and CMCase activity from Streptomyces albolongus $A_{5}$

\begin{tabular}{lccccc}
\hline $\begin{array}{l}\text { Carbon source } \\
(1.2 \%)\end{array}$ & Final pH & $\begin{array}{c}\text { Reducing } \\
\text { sugar } \\
(\mathrm{mg} / \mathrm{ml})\end{array}$ & $\begin{array}{c}\text { Saccharification } \\
(\%)\end{array}$ & $\begin{array}{c}\text { Soluble } \\
\text { protein } \\
(\mathrm{mg} / \mathrm{ml})\end{array}$ & $\begin{array}{c}\text { CMCase } \\
\text { activity } \\
(\text { Unit/ml) }\end{array}$ \\
\hline CMC & 7.1 & 309.4 & 2.58 & 196.4 & 120.2 \\
CMC + COA & 8.1 & 325.8 & 2.71 & 225.4 & 139.7 \\
Avicel & 7.6 & 78.1 & 0.65 & 110.0 & 70.2 \\
Avicel + COA & 7.2 & 92.1 & 0.77 & 129.3 & 87.2 \\
Filter paper & 7.5 & 82.8 & 0.69 & 118.2 & 50.3 \\
Filter paper + COA & 7.4 & 67.2 & 0.56 & 142.2 & 62.6 \\
\hline
\end{tabular}

The organism was grown in shake-flask culture in Winstead's medium with an initial $\mathrm{pH} 6.5$ containing $1.2 \%$ carbon source at $35^{\circ} \mathrm{C}$ for 5 days. ${ }^{a}$ One unit of the enzyme activity was defined as the amount of enzyme required to release glucose equivalents (in $\mathrm{mg} / \mathrm{ml}$ ) in $1 \mathrm{~h}$ under the defined conditions. CMCase = Carboxymethylcellulase; $\mathrm{COA}=$ Cellobiose octaacetate 
Table 3. Comparison of enzyme activities produced from Streptomyces albolongus $A_{5}$ on carboxymethylcellulose (CMC) with or without supplementation of cellobiose-octaacetate (COA)

\begin{tabular}{lcc}
\hline Enzyme & \multicolumn{2}{c}{$\begin{array}{c}\text { Enzyme activity (Unit/ml) } \\
\text { when grown on }\end{array}$} \\
\cline { 2 - 3 } & CMC & CMC + COA \\
\hline Carboxymethly cellulose (CMCase) & 136.7 & 154.7 \\
Filter paper cellulose (FPase) & 46.9 & 55.4 \\
Avicelase & 49.2 & 66.3 \\
$\beta$-Glucosidase & 36.8 & 125.2 \\
\hline
\end{tabular}

The organism was grown in shake-flask culture in Winstead's medium with an initial pH 6.5 containing $1.2 \%$ carboxymethly cellulose (CMC) and $0.2 \%$ beef extract with or without supplementation of $0.2 \%$ cellobiose

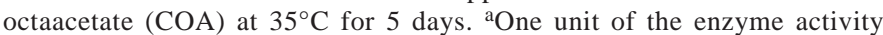
was defined as the amount of enzyme required to release glucose equivalents (in $\mathrm{mg} / \mathrm{ml}$ ) in $1 \mathrm{~h}$ under the defined conditions.

In this study, it was observed that, regardless of the substrate used, the enzyme production was enhanced to some extent in the presence of the inducer COA. Inductive formation of cellulolytic enzymes by microorganisms has been reported by many workers ${ }^{1-14,23}$. However, there is little of information available on the inductive synthesis of cellulase by COA. Recently, Nipa et al. ${ }^{24}$ reported that COA is an active inducer of cellulase (CMCase) from filamentous mesophilic fungus Aspergillus humicola. Therefore, it can be assume that COA acts as an inducer of cellulase both in prokaryotic and eukaryotic organisms.

\section{Acknowledgement}

The authors are grateful to the Ministry of Science and Information \& Communication Technology, Government of the Peoples Republic of Bangladesh for the grant under special allocation for the financial years 2000-2001 to support this study.

\section{References}

1. Eriksson KE \& Hamp SG. 1978. Regulation of endo-1,4-b-glucanase production in Sporotrichum pulverulentum. Eur J Biochem. 90: 183190.

2. Mandels M \& Reese ET. 1960. Induction of cellulase in fungi by cellobiose. J Bacteriol. 79: 816-826.

3. Canerascini M, Coudray MR, Rey JP, Southgate RJG \& Meier H. 1979. Induction and catabolite repression of cellulase synthesis in the thermophilic fungus Sporotrichum thermophile. J Gen Microbial. 110: 291-303.

4. Eberhart BM, Beck RS \& Goolsby KM. 1977. Cellulase of Neurospora crassa. J Bacteriol. 130: 181-186.

5. Eriksson KE. 1979. Biosynthesis of polysaccharides In Microbial Polysaccharases (Berkeley CW, Gooday GW \& Ellwood DC eds), pp. 285-293. Academic Press, London.
6. Knowles J, Lehtovaara P, Penttila M, Teeri T, Harkki A \& Salovuori I. 1987. The cellulase genes of Trichoderma. Antonie van Leeuwenhoek J Microbiol. 53: 335-342.

7. Mandels M, Weber J \& Parizek R. 1971. Enhanced cellulose production by a mutant of Trichoderma viride. Appl Microbiol. 21: 152-154.

8. El-Gogary S, Leite A, Crivellaro O, Eveleigh DE \& El-Dorry H. 1989. Mechanism by which cellulose triggers cellobiohydrolase I gene expression in Trichoderma reesei. Proc Natl Acad Sci USA. 86: 61386141.

9. Gong CS, Ladisch MR \& Tsao GT. 1979. Biosynthesis, purification, and mode of action of cellulases of Trichoderma reesei. Adv Chem Ser. 181: 261-288.

10. Hrmova M, Biely P \&Vrsanska M. 1986. Specificity of cellulase and b-xylanase induction in Trichoderma reesei QM9414. Arch Microbiol. 144: 307-311.

11. Nisizawa T, Suzuki H, Nakayama M \& Nisizawa K. 1971. Inductive formation of cellulase by sophorose in Trichoderma viride. $J$ Biochem. 70: 375-385.

12. Sternberg D. 1976. Production of cellulase by Trichoderma. Biotechnol Bioeng Symp. 6: 35-53.

13. Kamagata Y, Yachi M, Kurasawa T, Suto M, Sasaki H, Takao S \& Tomita F. 1991. Cellulase induction by cellobiose octaacetate in Penicillium purpurogenum. J Ferment Bioeng. 72: 217-220.

14. Suto M, Yachi M, Kamagata Y, Sasaki H, Takao S \& Tomita F. 1991. Cellulase induction by soluble acetyl 4-O-p-D-glucopyranosyl-Dglucosides (cellobioses) in Penicillium purpurogenum. J Ferment Bioeng. 72: 352-357.

15. Buchanan RE \& Gibbons NE. 1974. Bergey's Manual of Determinative Bacteriology, $8^{\text {th }}$ edn. The Williams \& Wilkins Co, Baltimore.

16. Somogyi N. 1944. A photometric adaptation of the Somogyi method for the determination of glucose. J Biol Chem. 153: 375-380.

17. Lowry OH, Rosebrough NH, Farr AL \& Randall RJ. 1951. Protein measurement with the Folin phenol reagent. J Biol Chem. 193: 265275.

18. Mahadevan A \& Sridhar R. 1982. Methods in Physiological Plant Pathology. Sivakami Publication, Madras.

19. Malek MA, Choudhury N, Chowdhury NA, Youssouf QM \& Mollah RA. 1987. Degradation of cellulosic substances by Cytophaga sp. Bangladesh J Microbiol. 4(1): 1-6.

20. Shailendra S, Bahadur J \& Ajit V. 1991. Production and localization of carboxymethyl cellulase, xylanase, and $\beta$-glucosidase from Cellulomonas and Micrococcus sp. Appl Microbiol Biotechnol. 34: 668-670.

21. Hossain FMM, Rahman MM, Choudhury N \& Malek MA. 1999. Production of extracellular carboximethyal cellulase and cellobiase by a thermophilic bacillus sp. Bangladesh J Microbiol. 16(2): 115125.

22. Farhana IS, Chowdhury NA, Choudhury N \& Malek MA. 2000. Growth and activity of extracellular cellulolytic enzymes of Micromonospora sp. T-24. Bangladesh J Microbiol. 17(2): 179-186.

23. Gomes DJ, Gomes J, Hoq MM \& Steiner W. 1995. Induction of cellulose degrading enzymes in Thermoascus aurantiacus. Bangladesh J Microbiol. 12(1-2): 23-29.

24. Nipa MN, Sultana S \& Hakim MA. 2006. Induction of cellulase biosynthesis by cellobiose octaacetate in Aspergillus humicola. Bangladesh J Microbiol. 23(2): 174-176. 